\title{
An Assessment of Sharps Injuries in Healthcare Workers
}

\section{Sağılık Çalıșanlarında Delici-Kesici Alet Yaralanmalarının Değerlendirilmesi}

\author{
๑ Nurten Nur AYDIN, ๑ Firdevs AKSOY, ๑ Gürdal YILMAZ, ๑ Iftihar KÖKSAL \\ Karadeniz Technical University Faculty of Medicine, Department of Infectious Diseases and Clinical Microbiology, Trabzon, Turkey
}

\begin{abstract}
Objectives: During the healthcare services, healthcare workers are under the risk of sharps and needle stick injuries. In this study, we evaluated occupational injuries seen in our hospital and emphasized the importance of reducing the risk of exposure to these injuries through compliance with infection control precautions.

Materials and Methods: In this study, we retrospectively evaluated the data of the Infection Control Committee of Karadeniz Technical University Faculty of Medicine on work-related sharp injuries among healthcare workers between 01.01.2016 and 01.02.2018.

Results: This study was carried out with sixty-six healthcare workers. The mean age of the healthcare workers was 29.3( \pm 7.62 ) years. The injuries were most frequently observed in nurses. Majority of the injuries had occurred in internal medicine clinics and most of them were needle stick injuries. In $99.7 \%$ of the injuries, contamination state was known. Forty-nine of 66 employees were immune to the hepatitis B virus. After the injuries, any acute viral infection was not developed. Three out of the 6 employees injured by positive serology of human immunodeficiency virus sources were given prophylaxis for four weeks after contact.

Conclusion: All healthcare workers should be informed about the measures against injuries, the proper use of protective equipment and the importance of vaccination and, they should be subjected to periodic training.

Keywords: Healthcare workers, sharps injuries, hepatitis B, hepatitis C, human immunodeficiency virus
\end{abstract}

ÖZ

Amaç: Sağlık bakım hizmetleri sırasında sağlık çalışanları delici kesici aletlerle yaralanma tehlikesiyle risk altındadır. Çalışmamızda hastanemizde görülen mesleki yaralanmaların değerlendirilmesi ve enfeksiyon kontrol önlemlerine uyumla maruziyet riskinin azaltılmasının önemine vurgu yapılmıştır.

Gereç ve Yöntemler: Çalışmamızda 01.01.2016-01.02.2018 tarihleri arasında Karadeniz Teknik Üniversitesi Tıp Fakültesi Hastanesi, Enfeksiyon Kontrol Komitesi'nin çalışan yaralanma kayıtları retrospektif olarak değerlendirildi.

Bulgular: Altmış altı sağ ık çalışanı formu çalışmaya alındı. Çalışanların yaş ortalaması 29,3 \pm 7,62 idi. Yaralanma en sık hemşirelerde görüldü. En fazla yaralanma dahili kliniklerde olmuştu. En fazla yaralanma iğne batması sonrası meydana geldi. Yaralanmaların \%99,7'sinde kontaminasyon durumu biliniyordu. Altmış altı çalışanın 49'u hepatit $B$ virüsne karşı bağışıktı. Yaralanma sonrası çalışanlardan hiçbirinde akut viral enfeksiyon gelişmedi. Insan immün yetmezlik virüsü pozitif kaynakla yaralanan 6 çalışanın 3'ü temas sonrası dört hafta profilaksi aldi.

Sonuç: Tüm sağlık çalışanları, yaralanmalara karşı önlemler, koruyucu ekipmanların uygun kullanımı ve aşılanmanın önemi konusunda bilgilendirilmeli ve periyodik eğitimler almalıdır.

Anahtar Kelimeler: Sağlık çalışanları, delici kesici alet yaralanmaları, hepatitis $B$, hepatitis $C$, insan immün yetmezlik virüsü

Aydın NN, Aksoy F, Yılmaz G, Köksal İ. An Assessment of Sharps Injuries in Healthcare Workers. Viral Hepat J. 2018;24:75-78.

This study was presented as a poster abstract at the 14 th $^{\text {th }}$ National Viral Hepatitis Congress on April 26-29, 2018.

\section{Introduction}

Healthcare workers are at risk of occupational exposure to infected blood and body fluids contaminated with hepatitis B virus $(\mathrm{HBV})$, hepatitis $\mathrm{C}$ virus $(\mathrm{HCV})$ and human immunodeficiency virus (HIV) that can cause significant mortality and morbidity $(1,2)$. Today, although many medical supplies are disposable and infection rates are low, sharps and need lestick injuries (NSI) continue to be the fact that healthcare workers frequently face (3). However, most of the contacts do not result in infection. Infections are mainly caused by mucosal and percutaneous injuries (4). In order to

Address for Correspondence: Nurten Nur Aydın MD, Karadeniz Technical University Faculty of Medicine, Department of Infectious Diseases and Clinical Microbiology, Trabzon, Turkey Phone: +90 4623775695 E-mail: nurtennurkenc@hotmail.com ORCID ID: orcid.org/0000-0003-4138-2490 Received: 09.07.2018 Accepted: 30.10.2018

${ }^{\circ}$ Copyright 2018 by Viral Hepatitis Society / Viral Hepatitis Journal published by Galenos Publishing House. 
reduce the risk of transmission of pathogens from infected blood or body fluids to healthcare workers, hand washing, proper use of protective barriers, adherence to the standard precautions when using needles and other sharp instruments are the most important protection methods for all healthcare workers (1). In this study, it was aimed to determine the occupational injury rates among healthcare workers at high risk for occupational exposure to NSI. In this study, the importance of compliance with infection control precautions in reducing the exposure risk was emphasized.

\section{Materials and Methods}

This study was carried out through retrospective examination of the data of the Infection Control Committee of Karadeniz Technical University Faculty of Medicine on work-related sharp injuries between 01.01.2016 and 01.02.2018. The data of sixty-six healthcare workers were evaluated. The healthcare workers were grouped as nurses, doctors, intern students, cleaning staff and technicians. Demographic characteristics of the injured employees, types of injury, use protective equipment, immunization status, and contamination states of the injuries were investigated. The data were recorded in excel format and the results were evaluated.

\section{Results}

Sixty-six healthcare workers with a mean age of $29.3 \pm 7.62$ years were exposed to NSI between 01.01.2016 and 01.02.2018. Twenty-three (34.9\%) of the subjects were male, 43 (65.1\%) were female. Among the professional groups, the biggest group consisted of nurses $(50 \%)$ followed by doctors $(16.7 \%)$, cleaning staff $(12.1 \%)$, technicians $(12.1 \%)$, and interns $(12.1 \%)$, respectively. Most of the injuries were observed in internal medicine clinics (33.3\%) followed by those in intensive care units $(18.2 \%)$, operating room (18.2\%), surgical clinics (15.1\%), emergency room (13.7\%) and in the phlebotomy department (1.5\%), respectively. A total of $68.2 \%$ of the employees were exposed to needle stick injury, $15.1 \%$ to mucosal contact with blood, $9.1 \%$ to sharps injury and, $7.6 \%$ of them were exposed to contact with other body fluids (Table 1).

During the injuries, 55 of the employees (83.3\%) were using gloves as the protective equipment. The contamination status was known in $99.7 \%$ of the injuries, whereas it was not known in $0.3 \%$ of them. During injuries, $22.7 \%$ of the employees were exposed to anti-HCV-positive sources, $13.6 \%$ to hepatitis B surface antigen (HBsAg)-positive sources and $9.1 \%$ were exposed to the positive HIV-positive sources. Forty-nine of 66 employees were immune to HBV. Because anti-HBs $<10$ IU was identified in 2 of the 9 employees exposed to HBsAg-positive source, HBV vaccine and immunoglobulin were administered. After the injuries, any acute viral infection was not developed in the employees. Three out of the $6(9.1 \%)$ employees injured by HIV-positive sources were given prophylaxis for four weeks after contact (Table 2). The other 3 employees did not use the recommended drugs for prophylaxis because of side effects, and for having negative HIV RNA testing after 6 months.

\section{Discussion}

Healthcare workers face many risks and dangers related to their occupation in the working environment. In terms of occupational exposure, NSI is a serious problem that can often be prevented. Similar injuries also occur in nursing homes, emergency care services, and other health care services, such as private homes. In infections, especially HBV, HCV, and HIV are associated with occupational contagion. However, more than 20 other pathogens can be transmitted by injury $(5,6)$.

Looking at the occupational groups of the 66 healthcare workers investigated in this study, it was observed that, most frequently, nurses had been exposed to injuries (50\%). In terms of other occupational groups, following the nurses, doctors (16.7\%), cleaning staff $(12.1 \%)$, technicians $(12.1 \%)$, and interns $(12.1 \%)$ had been exposed to injuries, respectively. In the literature, several studies, in which similar evaluations were made, also showed that nurses were the first group being most frequently exposed

\begin{tabular}{|l|l|}
\hline Table 1. The data of sharps and needlestick injuries \\
\hline Mean age & $29.3 \pm 7.62$ \\
\hline Gender & Number (\%) \\
\hline Female & $43(65.1 \%)$ \\
\hline Male & $23(34.9 \%)$ \\
\hline Job & Number (\%) \\
\hline Nurse & $31(50 \%)$ \\
\hline Doctor & $11(16.7 \%)$ \\
\hline Cleaning staff & $8(12.1 \%)$ \\
\hline Technicians & $8(12.1 \%)$ \\
\hline Intern students & $8(12.1 \%)$ \\
\hline Department & Number (\%) \\
\hline Internal clinics & $22(33.3 \%)$ \\
\hline Intensive care units & $12(18.2 \%)$ \\
\hline Operating room & $12(18.2 \%)$ \\
\hline Surgical clinics & $10(15.1 \%)$ \\
\hline Emergency room & $9(13.7 \%)$ \\
\hline Phlebotomy service & $1(1.5 \%)$ \\
\hline Type of injury & Number (\%) \\
\hline Pinprick & $45(68.2 \%)$ \\
\hline Mucosal contact with blood & $10(15.1 \%)$ \\
\hline Sharp objects & $6(9.1 \%)$ \\
\hline Contact with other body fluids & $5(7.6 \%)$ \\
\hline
\end{tabular}

Table 2. Healthcare workers exposed to injury and conditions of serology sources

\begin{tabular}{|l|l|}
\hline Healthcare workers & 66 \\
\hline Anti-HBs >10 IU & 49 \\
\hline HBsAg positive & - \\
\hline Anti-HCV positive & - \\
\hline Anti-HIV positive & - \\
\hline Source & $15(22.7 \%)$ \\
\hline Anti-HCV positive & $9(13.6 \%)$ \\
\hline HBsAg positive & $6(9.1 \%)$ \\
\hline Anti-HIV positive & $\begin{array}{l}\text { HBs: Hepatitis B surface, HBsAg: Hepatitis B surface antigen, HCV: Hepatitis C } \\
\text { virüs, HIV: Human immunodeficiency virus }\end{array}$ \\
\hline
\end{tabular}


to injuries $(6,7,8,9)$. In different studies, the frequency of injuries varies in different occupational groups in several studies. In a study carried out by Merih et al. (10), it was seen that the most frequently injured occupational group was the cleaning staff group with the rate of $71.9 \%$. Another study found that the most frequently injured occupational group was doctors with the rate of 56\% (11).

In a study, it was shown that most of the healthcare workers exposed to NSI did not report the injury and did not take the necessary precautions (12). Although the number of NSI cases seems to be low in our study, it is thought that the majority of healthcare workers considers injuries as insignificant and do not report. In a study carried out by Altıok et al. (13), it was indicated that $87.3 \%$ of the healthcare workers exposed to SNI did not report the injuries. The Centers for Disease Control and Prevention (CDC) estimates that 385.000 healthcare workers each year are exposed to $\mathrm{SNI}$ (6). Due to the missing data, it is not possible to assess the actual size of injuries among healthcare workers. Surveys on healthcare workers showed that at least $50 \%$ of occupational injuries were not reported $(14,15)$.

In a study conducted by Kişioğlu et al. (16), it was found that injuries were seen mostly in surgical clinics. In another study conducted with doctors, it was found that the commonest site in which such injuries were sustained was surgical clinics and it was reported that most of the injuries occurred during suturing (17). In contrast to the literature, in the present study, it was determined that the rate of $\mathrm{SNI}$ in internal medicine clinics was higher (33.3\%); this rate was $18.2 \%, 18.2 \%, 15.1 \%, 13.7 \%$ and $1.5 \%$ for intensive care units, operating rooms, surgery clinics, emergency clinics and the phlebotomy department, respectively. Studies available in the literature found that needlestick injuries were especially observed during needle recapping $(18,19)$. Similar to the literature, it was also determined in our study that injuries mostly occurred as a result of percutaneous needlestick injuries with the rate of $68.2 \%$.

The CDC recommended standard protection measures in 1982 and updated in the following years. According to these measures, blood and body fluids should be considered potentially infectious (18). In a prospective surveillance of percutaneous, mucous membrane, and cutaneous blood contacts among healthcare workers who provided home infusion therapy or performed procedures using needles or sharp instruments in the home setting, it was determined that masks, gowns and protective glasses or goggles were used in $52 \%, 5 \%$ and $2 \%$ of 14.744 procedure visits, respectively (20). Other studies in the literature have shown that the rate of protective equipment use varied between $55 \%$ and $68 \%$ and that the use of gloves was the most common $(18,21)$. In our study, it was found that $83.3 \%$ of healthcare workers used gloves as protective equipment, however, any data related to other protective equipment use was not determined.

In the case of injuries that occur as a result of contact with blood or body fluids, skin regions should be washed with soap and water, and the mucous membranes should only be washed with water $(18,21)$. In terms of potential HBV, HCV and HIV transmission, serologies of the healthcare worker exposed to INS and the source patient should be looked at. Today, prophylaxis is recommended against HBV and HIV after contact and employees should be evaluated in terms of immunization and prophylaxis (18). In this study, anti-HBS $>10 \mathrm{IU}$ was found in 49 of the participants. Those who were not immune were enrolled in the vaccination program. For $0.3 \%$ of the healthcare workers exposed to NSI, the source causing injury was unknown. In the cases where the source was known, $22.7 \%$ of the sources were found to be anti-HCVpositive, 3.6\% - HBsAg-positive, and 9.1\% were HIV-positive. In the case where the source was HBsAg-positive, because anti-HBs $<10$ IU was identified in 2 employees, HBV vaccine and immunoglobulin were administered. 3 out of the $6(9.1 \%)$ employees injured by HIV-positive sources were given prophylaxis for four weeks after contact. In a survey study, 3.8\% of the injured healthcare workers were reported to have contact-related HBV infection $0.3 \%$ had contact-related HCV infection (22). In the present study, the healthcare workers exposed to NSI were followed for 6 months and any acute viral infection was not developed in any of them.

\section{Conclusion}

Healthcare workers may experience occupational exposure to NSI during their health care services. This situation creates psychological stress on the employees especially in contaminated injuries. All the healthcare workers should be informed about the measures against injuries, the proper usage of protective equipment and the importance of vaccination. The trainings should be given periodically and the participation of healthcare workers in these trainings should be ensured. It is thought that the transmission frequency of infections will be reduced by full compliance with standard precautions and the correct use of protective equipment.

\section{Ethics \\ Ethics Committee Approval: Retrospective study. \\ Informed Consent: Retrospective study. \\ Peer-review: Externally peer-reviewed.}

\section{Authorship Contributions}

Surgical and Medical Practices: N.N.A., Concept: I.K., N.N.A., Design: F.A., N.N.A., Data Collection or Processing: N.N.A., F.A., Analysis or Interpretation: G.Y., F.A., N.N.A., Literature Search: N.N.A., Writing: N.N.A.

Conflict of Interest: No conflict of interest was declared by the authors.

Financial Disclosure: The authors declared that this study received no financial support.

\section{References}

1. Beltrami EM, Williams IT, Shapiro CN, Chamberland ME. Risk and management of blood-borne infections in health care workers. Clin Microbiol Rev. 2000;13:385-407.

2. Akova M. Sağlık Personeline Kan Yoluyla Bulaşan Infeksiyon Hastalıkları ve Korunmak Için Alınacak Önlemler. Hastane Infeksiyonları Dergisi. 1997;1:83-90.

3. Waterman J, Jankowski R, Madan I. Under-reporting of needlestick injuries by medical students. J Hosp Infect. 1994;26:149-150.

4. Trim JC, Adams D, Elliott PT. Healthcare workers' knowledge of inoculation injuries and glove use. Br J Nurs. 2003;12:215-221.

5. Wagner D, de With K, Huzly D, Hufert F, Weidmann M, Breisinger S, Eppinger S, Kern WV, Bauer TM. Nosocomial acquisition of dengue. Emerg Infect Dis. 2004;10:1872-1873.

6. VILARIÑO, Carmen Lameiro. Workbook for Designing Implementing, and Evaluating a Sharps Injury Prevention Program CDC 2008. Revista Enfermería del Trabajo. 2013;3:162-163. 
7. Sarı ND, Fincancı M, Soysal HF, Demirkıran N, Koyuncu $S$, Özgün Ö. Delici Kesici Alet Yaralanmalarının Bildirim Sıklığı Neyin Göstergesi. Haseki Tıp Bülteni. 2014;52:98-102.

8. Bozkurt S, Kökoğlu ÖF, Yanıt F, Kocahasanoğlu U, Okumuş M, Sucaklı MH, Güler S, Kuzhan N, Savrun A, Uçmak H. Sağlık çalışanlarında iğne batması ve cerrahi aletlerle olan yaralanmalar. Dicle Tip Dergisi. 2013;40:449-452.

9. Turan H, Togan T. Hastane Personelinde Görülen Kan ve Vücut Sıvılarıyla Illişkili Yaralanmaların Değerlendirilmesi. Klimik Journal/ Klimik Dergisi. 2013;26.

10. Merih YD, Kocabey MY, ÇIRPI F, Bolca Z, Celayir AC. Bir devlet hastanesinde 3 yıl içerisinde görülen kesici-delici alet yaralanmalarının epidemiyolojisi ve korunmaya yönelik önlemler. Zeynep Kamil Tıp Bülteni. 2009;40:11-15.

11. Gücük M, Karabey S, Yolsal N, Özden YI. Istanbul tıp fakültesi genel cerrahi kliniği çalışanlarında kesici-delici alet yaralanmaları. Hastane Infeksiyonları Dergisi.2002;6:72-81.

12. Özdemir EG, Şengöz G. 500 yataklı eğitim ve araştırma hastanesinde kesici delici alet yaralanmaları tutum ve bilgi düzeyi ölçüm anketi sonuçları. Haseki Tıp Bülteni. 2013;51:11-14.

13. Altıok M, Kuyurtar F, Karaçorlu S, Ersöz G, Erdoğan S. Sağlık çalışanlarının delici kesici aletlerle yaralanma deneyimleri ve yaralanmaya yönelik alınan önlemler. Maltepe Üniversitesi Hemşirelik Bilim ve Sanatı Dergisi. 2009;2:70-79.

14. Sohn S, Eagan J, Sepkowitz KA. Safety-engineered device implementation: does it introduce bias in percutaneous injury reporting? Infect Control Hosp Epidemiol. 2004;25:543-547.

15. Doebbeling BN, Vaughn TE, McCoy KD, Beekmann SE, Woolson RF, Ferguson KJ, Torner JC. Percutaneous injury, blood exposure, and adherence to standard precautions: are hospital-based health care providers still at risk? Clin Infect Dis. 2003;37:1006-1013.

16. Kişioğlu AN, Öztürk M, Uskun E, Kırbıyık S. Bir üniversite hastanesi sağlık personelinde kesici delici yaralanma epidemiyolojisi ve korunmaya yönelik tutum ve davranışlar. T Klin Tıp Bilimleri. 2002;22:390-396.

17. Raahave D, Bremmelgaard A. New operative technique to reduce surgeons' risk of HIV infection. J Hosp Infect. 1991;18 Suppl A:177-183

18. Service UPH. Updated US public health service guidelines for the management of occupational exposures to HBV, HCV, and HIV and recommendations for postexposure prophylaxis. MMWR Recommendations and reports: Morbidity and mortality weekly report Recommendations and reports. 2001;50(RR-11):1.

19. Kepenek E, Şahin-Eker HB. Bir Devlet Hastanesinde Çalışanlarda Meydana Gelen Kesici ve Delici Alet Yaralanmalarının Değerlendirilmesi. Klimik Journal/Klimik Dergisi. 2017;30(2).

20. Beltrami EM, McArthur MA, McGeer A, Armstrong-Evans M, Lyons D, Chamberland ME, Cardo DM. The nature and frequency of blood contacts among home healthcare workers. Infect Control Hosp Epidemiol. 2000;21:765-770.

21. Kaya Ş, Baysal B, Eşkazan AE, Çolak H. Diyarbakır Eğitim Araştırma Hastanesi sağlık çalışanlarında kesici delici alet yaralanmalarının değerlendirilmesi. Viral Hepatit Dergisi. 2012;18:107-110.

22. Erol S, Özkurt Z, Ertek M, Kadanalı A, Taşyaran MA. Sağlık çalışanlarında kan ve vücut sıvılarıyla olan mesleki temaslar. Hastane Infeksiyonları Dergisi. 2005;9:101-106. 